\title{
Fragile X Syndrome: A Genetic Disorder to Consider in Patients with Speech Delay
}

\author{
Frajil X Sendromu: Konuşma Gecikmesi Olan Hastalarda \\ Göz Önüne Alınması Gereken Genetik Bir Bozukluk
}

Tuba ÇELEN YOLDAŞ' ${ }^{1}$, Gülen Eda UTINE², Elif Nursel ÖZMERT'1 , Koray BODUROĞLU²

\author{
${ }^{1}$ Hacettepe University, Faculty of Medicine, Department of Child Health and Diseases, Developmental Pediatrics, Ankara, Turkey \\ ${ }^{2}$ Hacettepe University, Faculty of Medicine, Department of Child Health and Diseases, Child Genetics, Ankara, Turkey
}

\begin{abstract}
Fragile $X$ syndrome (FXS) is the most commonly detected single gene cause of intellectual disability (ID) and autism spectrum disorder (ASD). Comprehensive and multidisciplinary evaluation of patients with ID or ASD is essential for prudent management of any probable underlying condition. Herein we report a 4 years and 3 months old boy with speech delay, previously admitted to other clinics many times without any definite diagnosis. Physical examination revealed that he had hyperactivity, poor eye contact and dysmorphic features. He had global developmental delay and symptoms of ASD. The patient who had dysmorphic features was referred to pediatric genetics department with the suspicion of FXS. Southern Blot analysis revealed CGG repeat expansion in the range of full mutation. Maternal southern blot analysis revealed expanded CGG repeat in the range of premutation, and the family was given genetic counseling. The patient is still being followed-up at the developmental pediatrics department with an individual education program and other supportive treatments.

Children with FXS typically present with developmental delay. Although motor delays are often seen, these tend to be mild, and affected males most commonly come to hospital because of speech delay as the patient in this case. The present patient has both FXS and ASD diagnosis. As children with FXS may not have gross physical features, any child who has developmental delay, borderline intellectual abilities, ID or ASD with an unknown etiology should undergo molecular testing for fragile $X$ syndrome. It was aimed in this case to emphasize the importance of comprehensive and multidisciplinary evaluation of all patients referred with speech delay.
\end{abstract}

Key Words: Autism spectrum disorder, Fragile $\mathrm{X}$ syndrome, Language delay

\section{Öz}

Frajil $X$ sendromu (FXS), zihinsel yetersizliğin (ZY) ve otizm spektrum bozukluğunun (OSB) en sık rastlanan tek gen nedenidir. Olası bir altta yatan durumun akılcı yönetimi için ZY veya OSB'li hastaların kapsamlı ve multidisipliner değerlendirmesi gereklidir. Burada daha önce herhangi bir kesin teșhis konmadan başka kliniklere birçok kez başvuran 4 yıl 3 aylık konuşma gecikmesi olan bir çocuğu bildirmekteyiz. Fizik muayene ile hiperaktivite, kısıtlı göz teması ve dismorfik özellikleri gözlemlendi. Global gelişme gecikmesi ve OSB semptomları mevcuttu. Dismorfik özellik taşıyan hasta çocuk genetik departmanına FXS şüphesiyle yönlendirildi. Southern blot analizi, tam mutasyon araliğında CGG tekrar sayısı artışı ortaya koymuştur. Annenin Southern Blot analizi, premutasyon aralığında artmış CGG tekrar sayısı olarak sonuçlanmış ve aileye genetik danışmanlık verilmiştir. Hasta, halen gelişimsel pediatri bölümünde özel eğitim programı ve diğer destekleyici tedavileri ile takip edilmektedir.

FXS'li çocuklar genellikle gelişimsel gecikme ile kendini gösterirler. Motor gecikmeleri sıklıkla görülmekle birlikte, bunlar hafiftir ve etkilenen erkekler bu olguda olduğu gibi genellikle konuşma gecikmesi nedeniyle hastaneye başvurur. Hastamız hem FXS hem de ASD tanısı almış̦ı. FXS'li çocuklar aşikar fiziksel özelliklere sahip olmayabileceğinden, gelişimsel gecikme, sınırda zihinsel yetersizlik, nedeni bilinmeyen etiyoloji ile ZY veya ASD olan her çocuk Frajil X sendromu için moleküler teste tabi tutulmalıdır. Bu olguda konuşma gecikmesi ile başvuran bütün hastaların kapsamlı ve multidisipliner değerlendirilmesinin önemini vurgulamak amaçlanmıştır.

Anahtar Sözcükler: Otizm spektrum bozukluğu, Frajil X sendromu, Konuşma gecikmesi

Correspondence Address / Yazışma Adresi:

Tuba ÇELEN YOLDAŞ

Hacettepe Üniversitesi Tıp Fakultesi, Çocuk Sağlığı ve Hastalıkları Anabilim Dalı,

Gelişimsel Pediatri Bilim Dalı, Ankara, Turkey

E-mail: tamertuba@gmail.com
Received / Geliş tarihi : :04.02.2018 Accepted / Kabul tarihi : 26.03.2018

Online published : 28.05.2018

Elektronik yayın tarihi

DOI: 10.12956/tjpd.2018.359 


\section{INTRODUCTION}

Fragile X syndrome (FXS) is the most commonly detected single gene disorder which causes intellectual disability (ID) and autism spectrum disorder (ASD), with a frequency of approximately $1: 4000$ to 5000 (1). Although the prevalence may vary, the disorder affects all ethnic groups in the world. Fragile $X$ syndrome occurs due to a trinucleotide repeat (CGG) expansion mutation in the promoter region of the FMR1 (fragile $X$ mental retardation 1) gene. Comprehensive and multidisciplinary evaluation of patients with ID or ASD is essential for prudent management of any probable underlying condition (2).

\section{CASE REPORT}

A 4 years and 3 months old boy, previously evaluated in other clinics many times without any definite diagnosis, was referred to our outpatient clinic for speech delay. He had not experienced any prenatal, natal, or postnatal complication. Immunization, growth and nutrition follow-up had been conducted at a primary health care center. The hearing test, performed at another hospital, was normal. No one was reported to have intellectual or physical disability in the family. According to his mother, he had achieved developmental milestones at the expected age, except in the language domain. He had spoken his first meaningful two words at the age of two, and he had only ten words and no phrases when he was referred to our clinic.

Physical examination revealed that he had hyperactivity, poor eye contact and dysmorphic features. He was administered the Denver II developmental screening test and was found to be delayed in social-cognitive, fine motor, gross motor and language domains. Due to his global developmental delay (GDD), supportive treatment was planned including speech, occupational and physical therapy along with educational strategies. Furthermore, he had symptoms of autistic spectrum disorder (ASD), therefore the Gilliam Autism Rating Scale-2 was applied and the autistic disturbance index was found to be very high. He was referred to the child and adolescent psychiatry department and the diagnosis of ASD was confirmed. Psychopharmacologic intervention was started with risperidone to treat hyperactivity.

The patient had dysmorphic features including prominent ears, brachycephaly, prominent forehead, and hyperlaxity, and was referred to the pediatric genetics department with suspected fragile $X$ syndrome (Figure 1). Southern blot analysis revealed CGG repeat expansion in the range of full mutation. Maternal southern blot analysis revealed expanded CGG repeat in the range of premutation, and the family was given genetic counseling. The patient is still being followedup at developmental pediatrics department with an individual education program and other supportive treatments.

\section{DISCUSSION}

Children with fragile $X$ syndrome are usually referred with developmental delay in early childhood. Affected males are commonly seen in hospitals because of their speech delay, as was the case in our patient. Motor delays are often seen but tend to be mild. Hypotonia is often present in infancy, but ameliorates with age, and evolves into coordination and praxis problems at school age (2). Although females and higher-functioning males with FXS may have normal language development in their early years, they present behavioral problems including attention deficit hyperactivity disorder (ADHD), anxiety or learning difficulty during school years. Males with FXS have ID that range from moderate to severe in specific areas of cognition and language domain. Our patient had global developmental delay. IQ scores tend to decrease with age during childhood, which is not due to regression but rather to failure to keep the intellectual development at a normal rate. Adult males with FXS have IQ scores ranging from 40 to 50 on average, with a mental age of about 5 to 6 years $(2,3)$.

In the prepubertal period the clinical phenotype of males with fragile $X$ syndrome is subtle, so the diagnosis may be difficult in early years (4). In fact, it was reported in a parent survey that $24 \%$ of children with fragile $X$ syndrome had been seen by a health care provider on more than 10 occasions before fragile

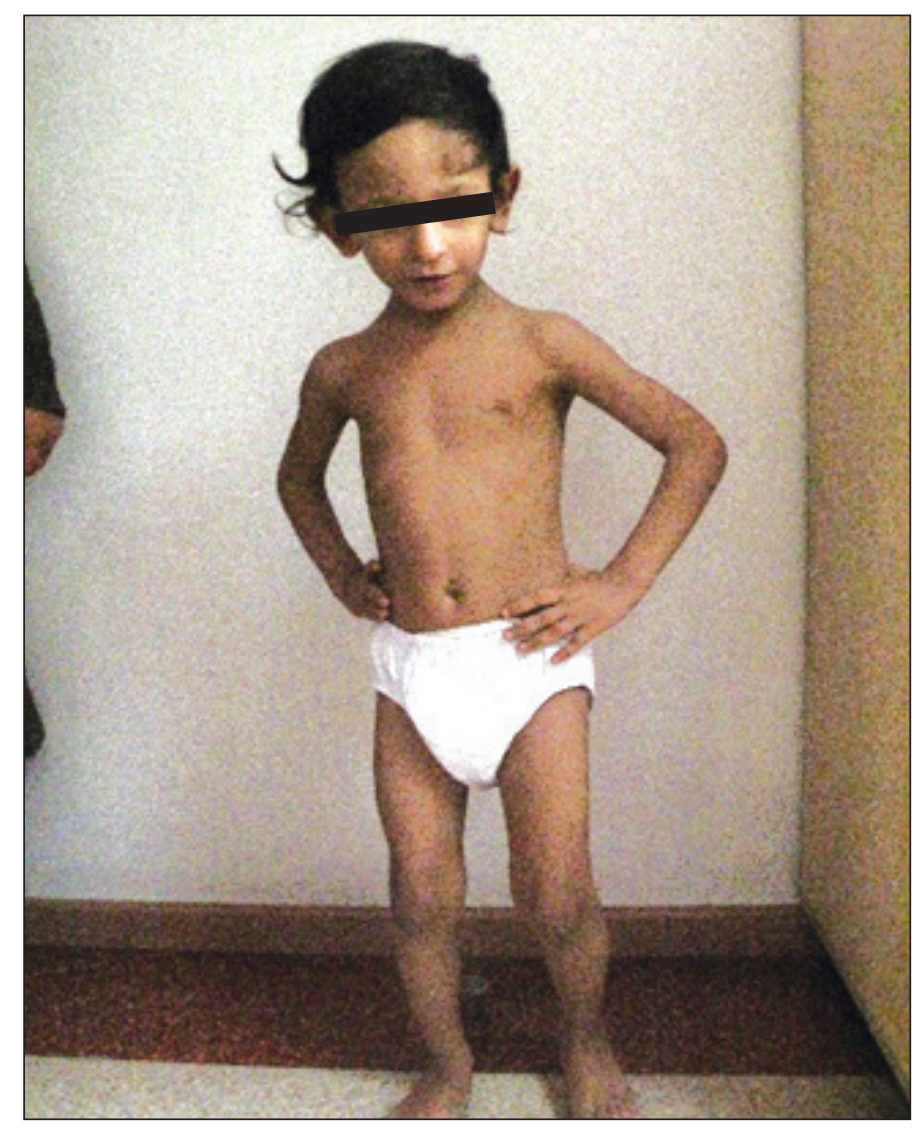

Figure 1: The photo of the presented patient. Note the prominent ears, long face and prominent forehead. 
$X$ testing was performed (5). The present patient was admitted many times to different hospitals.

Often, developmental delay, ID or specific behavioral patterns lead to suspicion of fragile $X$ syndrome. The classical facial appearance including a long and narrow face, a prominent forehead, a prominent jaw and protuberant ears may stay subtle until in late childhood or in early adolescence. Macroorchidism is more common after puberty. Chronic otitis media starts in infancy and can be seen in $60 \%$ to $80 \%$ of cases. Approximately $5 \%$ of females with a full mutation and $13 \%$ to $18 \%$ of affected males have seizures and may have relative macrocephaly. Birth weight is usually normal. Although linear growth is fast during childhood, growth rate tends to decline in adolescence. 26\% of adult men with fragile $X$ syndrome have a stature less than the 5 th percentile. Fragile $X$ syndrome also leads to connective tissue dysplasia that causes joint hypermobility, soft and velvety skin, congenital hip dislocation, pes planus, clubfoot, scoliosis and mitral valve prolapse. Feeding problems such as gastroesophageal reflux in infants are common $(4,6)$. The present patient had developmental delay, prominent forehead, prominent ears, joint hypermobility and also specific behavioral patterns, but was not diagnosed with fragile $X$ syndrome during the earlier visits to physicians.

Behavioral problems comprising attention problems, impulsivity, hyperactivity, anxiety, aggression, self-injury, mood lability, and autistic features such as self-talking, poor eye contact, hand flapping, hyperarousal to sensory stimuli are all evident in FXS $(2,7)$. Overall, $25-38 \%$ of FXS patients meet diagnostic criteria for autism in different age groups (8).

Characteristic features tend to vary in the FXS and ASD phenotypes. In FXS, a higher rate of ID, increased motor coordination deficits, poorer expressive than receptive language, generally higher interest in socialization (although limited by anxiety) and better imitation skills are seen than in ASD. Individuals who have both FXS and ASD, compared to those with only FXS, have lower $I Q$ and adaptive skills, decreased social interaction, more behavioral problems and less language acquisition (9).

Language delay is also prominent in early years. Speech in FXS may be delayed until 3 years of age. Deficiencies in conversational speech are more prominent than vocabulary and syntax deficits (4). Numerous factors influence language development including auditory working memory, sequential processing and sustained attention. These domains of cognition are involved in language learning. FXS causes deficiencies in social experiences required for typical language development (10). Typically developing children start to communicate with vocalizations and gestures and by about 9 months of age, they communicate intentionally with a partner. This is the period described as prelinguistic stage and is often prolonged in children with developmental disabilities, such as autism, Down syndrome and FXS (11). Roberts and colleagues suggest that the presence of autism was associated with an increased degree of language impairment in children with FXS. Autism negatively affects social interactions and children with autism often show deficits in prelinguistic skills, including pointing and joint attention (12). The importance of a responsive environment for language development is discussed in several studies. Maternal responsivity has been related to better language outcomes in both children with developmental disorders and in those with normal development. It is known that children of mothers who provide more linguistic input are more advanced cognitively and linguistically, compared to children of parents who communicate less with their children (11). However, biological mothers of children with FXS have either the full mutation or the premutation and may have some difficulties themselves, including cognitive deficits, depression and social anxiety, disturbing the interaction with their children (13). Also, if the child has associated ASD, this could impact responsivity and the severity of autistic symptoms would further disturb maternal-child interactions. Despite these speculations, there is insufficient research on responsive environment in motherchild dyads with FXS (11).

Currently supportive treatment is recommended in FXS, like in ASD, and should include speech, occupational, physical and educational therapy designed according to the pattern of cognitive and behavioral weaknesses and strengths of the individual. Medical problems like otitis media, strabismus, obstructive sleep apnea can impact development or behavior so treatment of these is also important. These are managed as required by individual needs of the patients. Behavioral problems in FXS need a consistent and intensive treatment approach that can be implemented at school, at home and in other areas. Also psychopharmacology for attention deficits, anxiety, or other problematic maladaptive behaviors is used to improve the overall functioning $(2,7)$.

Any child with developmental delay, borderline intellectual abilities, ID or ASD with unknown etiology should be considered for fragile $X$ molecular testing. The family should be given genetic counseling for the option of testing, also for other family members. Diagnosing fragile $X$ syndrome is important for the family, because it uncovers the reason why a child has behavioral problems and/or cognitive deficits. In this way the family can focus on appropriate management strategies to improve their child's developmental trajectories (4).

Individuals with fragile $X$ syndrome have challenges all through their lives. Diagnosing FXS early in life and coordinating the developmental, medical and behavioral services according to public resources is essential to increase the potential of affected people and decrease the stress of other family members. 


\section{REFERENCES}

1. Coffee B, Keith K, Albizua I, Malone T, Mowrey J, Sherman SL, et al. Incidence of fragile $X$ syndrome by newborn screening for methylated FMR1 DNA. Am J Hum Genet 2009;85: 503-14.

2. Yu TW, Berry-Kravis E. Autism and fragile $X$ syndrome. Semin Neurol 2014; 34: 258-65.

3. Berry-Kravis E, Grossman AW, Crnic LS, Greenough WT. Understanding fragile X syndrome. Curr Pediatr 2002;12:316-24.

4. Hersh JH, Saul RA. Committee on genetics. Health supervision for children with fragile X syndrome. Pediatrics 2011;127: 994-1006.

5. Bailey DB, Skinner D, Sparkman KL. Discovering fragile $X$ syndrome: Family experiences and perceptions. Pediatrics 2003; 111:407-16.

6. Hagerman RJ, Hagerman PJ. Fragile $X$ syndrome: Diagnosis, treatment, and research. 3rd ed. Baltimore, MD: Johns Hopkins University Press, 2002.

7. Berry-Kravis E, Sumis A, Hervey C, Mathur S. Clinic-based retrospective analysis of psychopharmacology for behavior in fragile x syndrome. Int J Pediatr 2012;2012: 843016.
8. Alanay Y, Ünal F, Turanlı G, Alikașifoğlu M, Alehan D, Akyol U, et al. A multidisciplinary approach to the management of individuals with fragile X syndrome. J Intellect Disabil Res 2007;51:151-61.

9. Wang LW, Berry-Kravis E, Hagerman RJ. Fragile X: Leading the way for targeted treatments in autism. Neurotherapeutics 2010;7:26474.

10. Finestack LH, Richmond EK, Abbeduto L. Language development in individuals with fragile $X$ syndrome. Top Lang Disord 2009;29:133-48.

11. Abbeduto L, Brady N, Kover ST. Language development and fragile $x$ syndrome: Profiles, syndrome-specificity, and within-syndrome di fferences. Ment Retard Dev Disabil Res Rev 2007;13:36-46.

12. Roberts JE, Mirrett P, Burchinal M. Receptive and expressive communication development of young males with fragile $X$ syndrome. Am J Ment Retard 2001;106:216-30.

13. Abbeduto L, Seltzer MM, Shattuck P, Krauss MW, Orsmond G, Murphy MM. Psychological well-being and coping in mothers of youths with autism, Down syndrome, or fragile $X$ syndrome. Am J Ment Retard 2004;109:237-54. 